\title{
N A forma é o real: Flaubert lido por Baudelaire e Maupassant
}

\author{
Júnior Vilarino Pereira
}

Universidade Federal de Viçosa, Brasil

http://orcid.org/0000-0003-3410-1179

\section{RESUMO}

O romance Madame Bovary, de Gustave Flaubert, quanto à sua influência, extrapola os limites de gêneros, épocas e movimentos literários e chega à contemporaneidade na posição de obra paradigmática tanto da inconversibilidade do real pela literatura quanto da irredutibilidade do literário a realidades pré-existentes. O objetivo deste artigo é mostrar que os escritores Charles Baudelaire e Guy de Maupassant ressaltam, em textos críticos sobre Madame Bovary, o formalismo e a impessoalidade da narrativa como recursos que instauram a imanência da obra e singularizam a pertença do autor à escola realista. O retorno a essas críticas pode lançar luz sobre experimentações estéticas posteriores em que a representação interroga o estatuto do documento e da referencialidade externa.

PALAVRAS-CHAVE: Gustave Flaubert; Romance moderno; Realismo; Crítica literária.

\section{The form is the real: Flaubert read by Baudelaire and Maupassant}

\section{ABSTRACT}

Gustave Flaubert's novel Madame Bovary, in terms of its influence, extrapolates the limits of genres, epochs, and literary movements, reaching contemporaneity in a position of paradigmatic work both for the inconvertibility of reality through literature and the irreducibility of the literary to pre-existing realities. The purpose of this article is to show that the writers Charles Baudelaire and Guy de Maupassant emphasize, in critical texts about Madame Bovary, the formalism and impersonality of the narrative as a posture that establishes the immanence of the work and singularize the author's belonging to the realist movement. The return to these criticisms may shed light on later aesthetic experiments in which representation questions the status of the document and of external referentiality.

KEYWORDS: Gustave Flaubert; Modern romance; Realism; Literary criticism. 


\section{Considerações iniciais}

Em artigo de 2007, “A Ficção de Milton Hatoum e a nova narrativa das minorias na América Latina", Raymond L. Williams destaca a ciência do foco narrativo pelo romancista amazonense como meio de regulação do conteúdo discursivo, apontando-o como um traço aprendido pelo autor em seu contato com o texto de Gustave Flaubert, comparação que estende também à obra do escritor peruano Mario Vargas Llosa:

A presença de Flaubert é visível (em Hatoum) na mesma forma que percebemos traços do escritor francês na ficção de Vargas Llosa: o controle preciso do narrador é, mais especificamente, uma consciência desenvolvida das consequências de quem narra as mudanças do ponto de vista. Nesse sentido, tanto Hatoum como Vargas Llosa são profundamente flaubertianos (WILLIAMS, 2007, p. 166).

Acrescentaríamos duas informações relacionadas com essa influência: Hatoum é tradutor de Flaubert; baseou-se, ainda, na personagem Félicité do conto Un Coeur Simple (1877), na composição da personagem Domingas no romance Dois Irmãos (2000). Llosa dedicou ao escritor francês um ensaio, A Orgia Perpétua (1979), verdadeira exegese de Madame Bovary (1856). Por outro lado, seria relevante constatar as lições flaubertianas para além de suas influências diretas em escritores contemporâneos, considerando-as como um momento inaugural a partir do qual a prosa de ficção não pôde mais ficar indiferente à imperiosidade de um trato relativo à dimensão referencial do documento e, mais especificamente, com o fato de ser a referência um meio, um fim ou ambos na construção do universo ficcional. Os prosadores se veriam, a partir de então, confrontados com uma questão constitutiva da natureza tanto formal quanto referencial da narrativa de ficção: a imanência ou a vinculação da matéria narrada ao mundo exterior. Assim, o debate sobre a representação realista não mais concerniria a este ou àquele escritor, mas se constituiria como cerne da criação, e a reflexão sobre a arte com menor ou maior grau de empenho referencial lidaria continuamente com o fato de a tessitura textual obedecer mais ou menos à coerção de leis inerentes ao fato narrativo propriamente dito.

Madame Bovary é uma obra em que essa questão predomina. Então, se a tese de Antoine Compagnon (1999) sobre a superstição do novo - segundo a qual a modernidade teria cada vez mais um tempo exíguo para firmar-se como tradição - é inquestionável, ela nos parece, em certa medida, relativa, em se tratando do romance Madame Bovary, cuja influência perene extrapola os limites de gêneros, épocas e movimentos literários, chegando à contemporaneidade como obra paradigmática tanto da inconversibilidade do real pela literatura quanto da irredutibilidade do literário a realidades pré-existentes. Daí a proposta de retorno ao romance de Flaubert e, extensivamente, a seleção das críticas sobre a obra escritas por Charles Baudelaire e Guy de Maupassant. No caso do poeta, por ter sido ele um dos primeiros críticos a depreenderem o esteticismo da obra, ainda em 1857, ano da primeira publicação em livro. Com efeito, o formalismo de Flaubert animou um vivo debate sobre a estética realista. Sainte-Beuve, escreve, para o Moniteur Universel, em 4 de maio de 1857, uma resenha na qual desta- 
ca que, no romance, não há lugar para "o acaso da pena"1 (citado em CÉRÉdl, 2006). George Sand, por sua vez, no texto "Le Réalisme", publicado em 8 de julho de 1857 em Le Courrier de Paris, chega a considerar, de forma suscinta, a qualidade estética da obra, que superaria qualquer conteúdo moral nele contido: "o que é belo nunca lesa"2 (citado em CÉRÉdl, 2006).

Entretanto, é Baudelaire, outro formalista, herdeiro da arte pela arte de Théophile Gautier, que desvendará ao público a combinação inédita de formalismo e realismo em Madame Bovary. Talvez por ele mesmo ter feito das transformações urbanísticas de Paris e do seu impacto sobre a experiência social no Segundo Império documentos prosaicos dos quais se apropriaria, porém, adulterando-os pelo idealismo poético, tornando-os índices menos remissivos, mais inventivos e menos documentais, conforme o postulado da imaginação, "a rainha das faculdades"3 (BAUDELAIRE, 2010, p. 366), defendida posteriormente no Salon de 1859. O poeta compartilhou tal idealismo com o próprio Flaubert, o que estreitou, na escrita formalista de cunho realista do século XIX, as relações entre poesia e romance. Enfim, creio ser relevante retomar a crítica de Baudelaire por ser a defesa da arte impessoal um distintivo da escrita de ambos os autores, o que me leva a ver no flâneur baudelairiano uma persona que viria a ser a versão poética da impessoalidade narrativa flaubertiana.

Maupassant foi escolhido por ter sido ele o discípulo eleito de Flaubert e ter produzido, além de críticas sobre o mestre, textos teóricos sobre o então chamado romance realista, termo que ele criticou, em seu ensaio "Le Roman", mediante uma proposta defensora da "ilusão completa da verdade"4 (1999, p. 76). Em certa medida, a discussão sobre a ilusão do real e a ênfase na imanência da obra remetem à crença dos românticos no poder da arte, à sua reivindicação de autonomia das esferas institucionais e, principalmente, à sua chancela para que a experiência do presente passasse a constituir o objeto artístico, conquistas estas, aliás, que muito devem ao "Prefácio" da peça Cromwell, que Victor Hugo lançara em 1827 em tom de manifesto: "O caráter do drama é o real; o real resulta da combinação bem natural de dois tipos: o sublime e o grotesco, que se cruzam no drama, como se cruzam na vida e na criação" (1988, p. 42). Em 1830, a polêmica relativa à peça Hernani, do mesmo Hugo, cujo estopim foi a fala da personagem Don Carlos perguntando que horas eram, considerada prosaica demais pela crítica classicista, é reveladora da emergência de uma arte voltada para a realidade presente ou, como mostrou Arnold Hauser, para "a sociedade burguesa moderna, a arte e a literatura naturalistas modernas, em suma, nosso próprio mundo" (1995, p. 725). Enfim, é somente depois de ser reivindicada, para a banalidade do real, a dignidade de ser representada, que ela pôde ser relativizada em proveito do culto da forma. Logo, nas obras singulares de Flaubert, Baudelaire e Maupassant, como em um diálogo teórico, crítico e criativo, a obra em si, com sua coerência interna, despontou enquanto valor único face à banalidade do real, que ela ordena segundo lógicas linguageiras.

\footnotetext{
1 "hasard de la plume". Todas as traduções do francês são livres e de minha autoria.

2 "ce qui est beau ne nuit jamais".

3 "la reine des facultés".

4 "illusion complète du vrai".
} 
Em 1856, Madame Bovary teve sua primeira publicação na Revue de Paris. Essa revista efetuou cortes na obra a mando dos censores de Napoleão III, mas isso não bastou para que o escritor não sofresse um processo judiciário por desrespeito à moral, em 1857. Charles Baudelaire - que não havia publicado As Flores do Mal e mal podia saber que, em agosto daquele mesmo ano, também se veria às voltas com o processo que sofreria por seu livro de poemas -, no calor da polêmica do julgamento de Gustave Flaubert, escreve uma crítica sobre seu romance na qual se dá ênfase à forma. Já no início do texto, o poeta celebra a absolvição do romancista, dizendo, com a ironia que lhe é peculiar, que "se os magistrados tivessem descoberto alguma coisa de verdadeiramente reprovável no livro, eles o teriam inocentado mesmo assim, em favor e em reconhecimento da BELEZA de que ele é revestido" (BAUDELAIRE, 2011, p. 8).

Décadas depois, será Guy de Maupassant que tornará a ressaltar esse formalismo em vários textos, dos quais o mais completo é "Estudo sobre Gustave Flaubert", de 1884. Contrapondo-o a Balzac, de quem destacou a "linguagem forte, cheia de imagens" (MAUPASSANT, 1990, p. 28), o ensaísta sublinhou a "linguagem admirável e nova" (1990, p. 29) do autor de Madame Bovary, qualificando-a como "precisa, sóbria e sonora" e identificando em seu método "um estudo da vida humana profundo, surpreendente, completo" (1990, p. 29).

Como se percebe, as motivações críticas de ambos os escritores dialogam ao lerem Flaubert, pois assinalam a autorreferencialidade de seu romance. Os imaginários sociais veiculados pela obra devem ser, para Baudelaire, pensados sob o prisma do que poderíamos chamar de uma lei interna à obra, ao que o crítico chamará "beleza”. Maupassant, por sua vez, inicialmente destaca o trabalho de Flaubert com a linguagem, para consentir posteriormente que a prosa deste último mantém suas relações com um objeto externo à obra, o qual ele nomeia "vida", mas que ela estuda em profundidade, e não - como podemos inferir por oposição como uma reprodução da superfície da realidade e das meras causalidades da autoria. O romance, ao contrário, "era a própria vida surgindo" (1990, p. 29).

Portanto, ao se analisar a leitura crítica dos dois escritores sobre Flaubert, percebe-se não apenas que, segundo eles, o feitio do enunciado tem maior relevância do que a sua referencialidade externa, mas que a forma acabaria, por assim dizer, convertendo-se no real da obra, isto é, a única referência em que se fiar, a única realidade passível de manejo, cuja "própria vida" vai "surgindo" de si, instaurando todos os reais que ela possa inventar e a que possa aludir. Real, ideia, conteúdo, documento, fonte: noções que, em Madame Bovary, segundo Baudelaire e Maupassant, representam muito pouco, ou talvez pudéssemos propor que só representassem o "nada", uma ideia que remete ao vazio da representação, tão posterior a Flaubert, mas que já lhe havia ocorrido e ficou eternizada em uma de suas mais célebres frases: "O que eu gostaria de fazer é um livro sobre nada, um livro sem vínculo exterior, que se sustentasse por si mesmo e pela força interna do seu estilo"'5 (FLAUBERT, 1980, p. 31).

\footnotetext{
5 "Ce que je voudrais faire, c'est un livre sur rien, un livre sans attache extérieure, qui se tiendrait de lui-même par la force interne de son style..." Carta a Louise Colet de 16 de janeiro de 1852.
} 


\section{A luz opalina da escrita: Baudelaire lendo Flaubert}

Alguns fatores ligam Baudelaire à estética realista. Mencionarei sucintamente críticas que ele lhe fez, anteriores à publicação de seu texto sobre Madame Bovary. No Salon de 1846, ele falará da "luta" entre a natureza e o artista: "A questão para ele não é copiar, mas interpretar em uma língua mais simples e luminosa"6 (BAUDELAIRE, 1951, p. 100). Em 1848, o poeta chegou a ser representado por Gustave Courbet na tela Portrait de Charles Baudelaire, que marca a transição do pintor do romantismo ao realismo ${ }^{7}$. Por outro lado, em Exposition Universelle de 1855, refere-se à concepção de Courbet como um sacrifício feito à "natureza exterior, positiva, imediata" (BAUDELAIRE, 1951, p. 154). Como vimos, o posicionamento ambíguo do poeta relativo ao realismo e sua inabalável teoria da estetização da realidade aproximam-no do formalismo de Flaubert.

A postura crítica de Baudelaire frente ao trabalho de Flaubert explora relações intertextuais entre as criações e as posturas literárias dos dois. Logo, o lirismo antiburguês, que viria a ser fundamento de As Flores do mal, é a mesma resposta estética que, segundo o poeta, o romancista formula contra a "concupiscência ardente [de uma] sociedade que abjurou definitivamente todo amor espiritual e que, negligenciando suas antigas entranhas, só se preocupa com suas vísceras" (BAUDELAIRE, 2011, p. 8, grifo do original). Assim, não apenas o estético prevalece sobre o real, mas ele o faz ancorado no presente e cultuando o passado, as "antigas entranhas". Como se sabe, o parâmetro do verso baudelairiano é o alexandrino de Racine, com o rigor formal nele executado. Talvez as entranhas a que Baudelaire aluda lendo a frase de Flaubert sejam justamente a herança da mais formalista poesia francesa, a busca da dignidade da forma, antagônica da perda do idealismo formal acarretada pelo gosto burguês. Ele se refere a esse gosto com uma metáfora do baixo corporal: as vísceras. Não poderia ocorrer-lhe imagem mais realista do que essa. É como se houvesse um prosaísmo escatológico que o trabalho estético poetiza. A imagética não poderia ser mais baudelairiana, ecoando a estética de As Flores do Mal, em que a planura asfixiante do spleen é medida pelo ritmo vivaz do ideal. O ideal dá forma ao vazio da experiência mundana, o que se verifica no poema "Une charogne", no qual a carcaça de um animal é disputada por uma cadela, que dela quer apoderar-se, com o sujeito poético, que impede à carniceira de aproximar-se, enquanto ele realiza seu trabalho de observação daquele objeto votado ao nada, esboçando mental e visualmente suas "formas [que] se apagavam", retendo sua "forma e essência divina” (BAUDELAIRE, 1983, p. 32).

Em seguida, Baudelaire revisa as produções romanescas daqueles tempos, entre as quais as de Champfleury ${ }^{10}$, considerando terem sido todas elas frustradas por não conseguir renovar o romance, aquilo que, segundo ele, apenas Flaubert conseguiu: ir além do horizonte de leitura

\footnotetext{
6 "Il ne s'agit pas pour lui de copier, mais d'interpréter dans une langue plus simple et plus lumineuse".

7 Para um aprofundamento das relações de Baudelaire com o realismo ver YOSHIO (1966).

8 "nature extérieure, positive, immédiate".

9 "les formes s'effaçaient" ; "la forme et l'essence divine".

${ }^{10}$ Faz-se oportuno mencionar o texto Du Réalisme, que Champfleury escreveu em forma de carta a George Sand, no qual sai em defesa do arrojado Courbet, que tivera sua tela, 0 Ateliê do Artista, recusada pelo Comitê da Exposição Universal de 1855 (CHAMPFLEURY, 2014, p. 464-473).
} 
do leitor burguês, cuja ideologia filisteia havia grassado naquelas últimas décadas. De fato, Baudelaire ressalta certa coerência de Flaubert com uma espécie de Zeitgeist da sociedade burguesa consolidada e empobrecida intelectualmente. Assim, "o novo romancista se via diante de uma sociedade absolutamente esgotada - pior que esgotada -, empobrecida e glutona, que se horrorizava com a ficção e amava apenas a posse" (BAUDELAIRE, 2011, p. 11). Era preciso, pois, desestabilizar a ideologia burguesa, nem tanto pelo tema, mas pela poética, pois "os últimos anos de Luís Filipe tinham visto as últimas explosões de um espírito ainda excitável pelos jogos da imaginação" (2011, p. 11).

Quanto aos recursos textuais de sua crítica, Baudelaire adotará a transferência de pessoa gramatical como um expediente retórico. $\mathrm{O}$ crítico formula perguntas e respostas sobre o método de composição de Madame Bovary, como se o próprio romancista as tivesse formulado:

\begin{abstract}
Em condições parecidas, um espírito bem nutrido, entusiasta do belo, mas formado em uma esgrima virtuosa, julgando ao mesmo tempo o bom e mau das situações, deve ter-se dito: "Qual é o meio mais seguro de agitar todas essas velhas almas? $\mathrm{Na}$ realidade, elas ignoram aquilo de que iriam gostar; somente sentem uma repulsa ativa pelo grandioso; a paixão ingênua, ardente, o abandono poético as faz corar e as fere (BAUDELAIRE, 2011, p. 11).
\end{abstract}

Cumpre observar o intertexto com As Flores do Mal, com a alegoria da "fantasiosa esgrima" no poema "Le Soleil", com a qual o sujeito poético define seu método: "Vou exercitar-me, só, em minha fantasiosa esgrima / Farejando em todos os cantos os acasos da rima"11 (BAUDELAIRE, 1983 , p. 83). Trata-se de estetizar quando não restaria senão condescender - como Baudelaire viria a fazer, aliás - com a realidade prosaica: "Sejamos então vulgares na escolha do tema, já que a escolha de um tema grandioso demais é uma impertinência" (BAUDELAIRE, 2011, p. 11). Na sequência, o crítico debate sobre o realismo propriamente dito, enfatizando a impessoalidade do foco narrativo flaubertiano: "evitemos nos deixar levar e falar por nossa própria conta. [...] Sejamos, como disse a escola, objetivos e impessoais" (2011, p. 12).

Como apontei anteriormente, o recurso da transferência de pessoa para responder às perguntas que Baudelaire põe na boca de Flaubert é significativo, porque o uso do pronome "nós", penso eu, permite-lhe praticar em seu texto crítico aquilo que o próprio romancista praticou: estratégias narrativas para escamotear o eu, das quais a mais relevante seria o discurso indireto livre. Sugiro, pois, que o "nós" expressa, implicitamente, a posição pessoal do poeta, como se ele anunciasse a impessoalidade do flâneur de seus poemas, reconhecendo-se em Flaubert. A crítica converteu-se, portanto, em um exercício de estilo de Baudelaire, que nos lembra o uso do pronome "nós" pelo narrador de Madame Bovary, em cuja abertura já se lê: "Estávamos em aula"12 (FLAUBERT, 1947, p. 3). Desse modo, assim como o narrador do romance se assume testemunha da matéria narrada - a situação cômica e trivial em que Charles Bovary pronuncia mal seu nome e é escarnecido pelos alunos -, Baudelaire soma-se ao número dos

\footnotetext{
11 "Je vais m'exercer seul à ma fantasque escrime / Flairant dans tous les coins les hasards de la rime".

12 "Nous étions à l'étude".
} 
escritores que se renderiam a banalidades dessa natureza, escrevendo, pois, "sejamos então vulgares" (BAUDELAIRE, 2011, p. 11).

Quanto ao termo "realismo", o poeta critica-o, dizendo ser ele uma "injúria repulsiva jogada no rosto de todos os analistas, palavra vaga e elástica" (BAUDELAIRE, 2011, p. 12), e impertinente para designar Madame Bovary, cujo texto estabelece um "novo método de criação" e não uma "descrição minuciosa dos acessórios" (2011, p. 12). Com essa contraposição, Baudelaire destaca a irrelevância da realidade face à relevância do trabalho narrativo em si. Ele enfatizará a supremacia da forma sobre a banalidade do real, servindo-se do termo estilo, tão caro, aliás, ao próprio Flaubert: "Aplicaremos um estilo nervoso, pitoresco, sutil, exato, sobre uma tela banal" (2011, p. 12). Ainda sobre o estilo, dirá, como se o dissesse o próprio Flaubert:

Não preciso me preocupar com o estilo, com o arranjo pitoresco, com a descrição dos ambientes; possuo todas essas qualidades com uma força superabundante; andarei apoiada na análise e na lógica, e provarei assim que todos os assuntos são indiferentemente bons ou ruins, segundo a maneira por que são tratados, e que os mais vulgares podem se tornar os melhores (BAUDELAIRE, 2011, p. 13).

Novamente, é minimizada a relevância da matéria extraída da realidade, e a tônica recai na "maneira", nos recursos composicionais. A análise salienta o recurso da perspectiva narrativa como meio de manipulação da realidade, explorando seus significados distintos, fundando a relatividade do real e a primazia do fictício. Com relação à moral, Baudelaire assinala o fato de não haver no romance personagem que seja alter ego do autor, que interprete e conclua. Essa tarefa, diz-nos ele, caberá ao leitor, "quem deve tirar as conclusões da conclusão" (2011, p. 13). A leitura baudelairiana reforça a imanência do romance: "Uma verdadeira obra de arte não precisa de requisitório. A lógica da obra basta para todas as postulações da moral” (2011, p. 13). Como a moral é um conteúdo exterior à obra, entrará nela unicamente pelas portas do estilo. Assim, a realidade, para Baudelaire, deveria ter por referência o texto, permanecendo irredutível a representações sociais, históricas imediatas. Aliás, no ensaio “O Efeito de Real”, em que Roland Barthes retoma o descritivismo realista pela ótica da semiologia, ele realça o caráter antirrepresentativo do romance de Flaubert:

\footnotetext{
Por sorte, se bem que a descrição de Rouen seja perfeitamente "impertinente" em relação à estrutura narrativa de Madame Bovary (não se pode ligá-la a nenhuma sequência funcional, nem a nenhum significado caracterial, atmosferial ou sapiencial), ela não é de forma alguma escandalosa, encontra-se justificada, se não pela lógica da obra, pelo menos pelas leis da literatura: seu "sentido" existe, depende da conformidade, não ao modelo, mas às regras culturais da representação" (BARTHES, 1972, p. 40).
}

Enfim, permitindo-me fazer um pastiche da asserção de Baudelaire, seria possível pensar que sua leitura de Madame Bovary concebe o romance como obra [que] basta para todas as postulações do real, bem como para distintas postulações naturalistas, marcando toda uma geração de escritores, entre eles o próprio Émile Zola. O romance de Flaubert se constituirá, igualmente, em uma via condutora ao romance formalista do século XX, que Julio Cortazar, em "A Situação 
do Romance", classificou como o romance de matriz poética, cuja ênfase se volta ao significante e cujos escritores paradigmáticos são Proust, James Joyce e Virgina Woolf: "O que importa é mostrar mais uma vez que no romance não há fundo e forma; o fundo da forma, é a forma. Prova-o o fato de que a linguagem de raiz poética não se presta para a reflexão, para a descrição objetiva, cujas formas naturais estão na prosa discursiva (CORTÁZAR, 2006, p. 74).

Outro traço do esteticismo enfatizado na crítica de Baudelaire é a concepção da psicologia de Emma Bovary: "Em suma, esta mulher é realmente grande, ela é sobretudo digna de se lamentar, [...] todas as mulheres intelectuais lhe serão reconhecidas por ela ter elevado a fêmea a uma tão alta potência" (BAUDELAIRE, 2011, p. 16). Aqui se destaca uma espécie de "lente de aumento"13 (MAUPASSANT, 1990, p. 11), que cria uma desproporção entre o possível e o narrável ou, se quisermos, entre o verossímil e o improvável, visto que a heroína tem atitudes destoantes do que Baudelaire sugeriu como um lugar social do feminino. Assim, ela possui um "duplo caráter de cálculo e de sonho que constitui o ser perfeito" (BAUDELAIRE, 2011, p. 16), duplicidade que estaria mais para o impossível do que para a realidade. Não haveria lugar para Emma Bovary, nem no mundo fictício, nem no mundo referencial, pois ela extrapola os horizontes de expectativa do leitor sobre o que fosse o papel social da mulher.

Se, como propôs Georg Lucaks (2000), o Frederico de L'Éducation sentimentale (1869) representa o "romantismo da desilusão", Emma Bovary talvez ainda conserve algo do Quixote, cuja alma é vista, na tipologia romanesca daquele teórico, como maior do que a realidade. Assim, diríamos que a disposição anímica de Emma é ampliar-se, mas à proporção que a realidade provinciana e burguesa do universo narrado igualmente ampliam-se. Para a desproporção entre a grandiosidade da heroína e a insignificância da realidade, Baudelaire constrói a metáfora da distorção ótica à qual a luz da escrita submete o exterior, pois ela pousa "um véu de glória sobre aventuras de mesas de cabeceira, sempre repugnantes e grotescas, quando a Poesia não as acaricia com sua claridade de luminária opalina” (BAUDELAIRE, 2011, p. 17). A prosa de Flaubert é, portanto, artificial, uma luminária, como os tantos objetos que, sonhados pelo eu-lírico do poema "Rêve parisien", seriam “imensos espelhos fascinados por tudo quanto refletiam"14 (BAUDELAIRE, 1983, p. 102).

\section{3. "A forma é a própria obra": Maupassant lendo Flaubert}

A imagem da luz ou de um objeto que desnaturaliza a visão comparece mais de uma vez nas críticas de Maupassant sobre Madame Bovary. No primeiro texto que escreveu sobre o autor, intitulado "Gustave Flaubert", de 1876, sob o pseudônimo de Guy de Valmont, emprega a metáfora da lente para referir-se brevemente a Balzac, que criava personagens

[...] através de uma lente de aumento, tornando-as por isso mesmo mais impressionantes e de certa maneira mais verdadeiras que a realidade! Madame Bovary aparece e provoca uma confu-

\footnotetext{
13 "Lente de aumento" é uma expressão utilizada por Guy de Maupassant para referir-se à impressão de realidade da prosa de Balzac, que será retomada adiante.

14 "D’immenses glaces éblouies / Par tout ce qu'elles reflétaient !"
} 
são geral. Por quê? Porque Flaubert é um idealista mas também e sobretudo um artista e seu livro era além disso um verdadeiro livro; porque o leitor, sem se dar conta, sem saber, sem compreender sofreu a influência todo-poderosa do estilo, a luz da arte que ilumina todas as partes desse livro (MAUPASSANT, 1990, p. 11).

Não surpreende que Balzac seja enaltecido, afinal, como sabemos, ele havia sido tão idealista quanto Flaubert, o que é um critério valorativo para Maupassant. Porém, segundo este último, faltaria estilo a Balzac. Em Flaubert, ao contrário, o estilo é o elemento mais impactante na recepção da obra e não a impressão causada pela potência das personagens. Destaca-se, nessa primeira análise de Maupassant, a ênfase em uma disciplina da forma, tanto do ponto vista do criador quanto do receptor. Assim, pode-se dizer que escandalizar o burguês consiste menos em destinar-lhe enredos perturbadores quanto ao conteúdo do que lhe endereçar narrativas cuja forma desconcerta e exige um apuro estético no processo de significação. A propósito, Robert Jauss verá no uso do discurso indireto livre em Madame Bovary um recurso que impunha aos leitores "uma estranha e surpreendente incerteza do julgamento"15 (JAUSS, 1978, p. 85). Maupassant, ironizando o leitor da época, que julgava ser a forma uma construção sonora e imponente, faz questão de precisar que, em Flaubert, "a forma é a própria obra" (MAUPASSANT, 1990, p. 12). Isso nos soa arrojado, como uma espécie de vaticínio pertinente para pensarmos inclusive o posterior formalismo de Rimbaud e Mallarmé, e do nouveau roman. Aliás, no ensaio "O Romance", prefácio da obra Pierre et Jean (1888), ele pagará tributo aos simbolistas: "Seu sonho de artistas é respeitável, e eles têm de particularmente interessante o fato de que conhecem e proclamam a extrema dificuldade da arte" (MAUPASSANT, 1990, p. 120).

O culto da forma flaubertiano consiste, para Maupassant, na justeza da expressão, resultante de uma vinculação imprescindível entre forma e ideia: "variável ao infinito como as sensações, as impressões e os pensamentos diversos, ela [a forma] adere a eles, tornam-se inseparáveis" (MAUPASSANT, 1990, p. 12). O que o crítico faz é repercutir a doutrina do próprio romancista, assim reportada: "Entre todas estas expressões, todas estas formas, todas estas estruturas, há apenas uma expressão, uma estrutura e uma forma para exprimir o que quero dizer" (MAUPASSANT, 1990, p. 74, itálico no original). Com a ideia da forma precisa, o crítico propõe uma concepção inovadora para o que se convencionou chamar estilo à época: "com efeito, chama-se geralmente estilo uma forma particular de frase própria a cada escritor". No entanto, "Flaubert não tem seu estilo, mas tem o estilo" (1990, p. 12). Assim, estilo não é, para Maupassant, uma singularidade formal, a dicção do texto, sua poética irredutível. Daí existir apenas o único estilo, a busca da expressão exata. Poderíamos considerar, contemporaneamente, que tal expressão tangencie o limite da própria linguagem, pois da língua será preciso extrair, entre tantos significantes, aquele que dê "contorno à ideia", não sendo a ideia o que será extraído (1990, p. 12). Não caberia aqui levantar a questão da arbitrariedade do signo em Flaubert, pois, como bem observou Roland Barthes, em "O Efeito de Real":

15 "une étrange et surprenante incertitude du jugement". 
A desintegração do signo - que parece muito bem ser o grande caso da modernidade - está certamente presente na empresa realista, mas de uma forma regressiva de algum modo, uma vez que se faz em nome de uma plenitude referencial, quando hoje, ao contrário, se trata de esvaziar o signo e de recuar infinitamente seu objeto até colocar em discussão, de maneira radical, a estética secular da "representação" (BARTHES, 1972, p. 41).

Obviamente, não é a questão da estrutura que o Flaubert lido por Maupassant levanta, mas podemos dizer que, para o crítico, é como se o significante antecedesse o significado, pois o conceito apenas se constituirá enquanto tal quando a forma exclusiva expressar a ideia. Assim, a ênfase na irredutibilidade da linguagem situa não apenas Madame Bovary, mas, sobretudo, a crítica de Maupassant entre abordagens literárias e teóricas subversoras do mimetismo realista.

Consequentemente, a exemplo de Baudelaire, que defendeu a predominância de uma moral interna em Madame Bovary, também Maupassant proporá a imanência da arte como o próprio "lema" de seu autor: "ele pensa que a primeira preocupação de um artista deve ser criar o belo; pois sendo a beleza uma verdade em si mesma, o que é belo é sempre verdadeiro" (MAUPASSANT, 1990, p. 13). Assim, a palavra "forma”, que ele já havia associado à noção de estilo, será então vinculada ao conceito de belo. E ele precisa: trata-se do "belo estético", segundo o qual coisas belas e feias perdem totalmente seu sentido apriorístico, quando passadas pelo crivo de um "intérprete". O que se deve evitar, pois, são as "fealdades de uma frase mal feita" (1990, p. 13).

De fato, o pensamento crítico de Maupassant sobre Flaubert estabelece intertextualidade com a arte pela arte. E o "belo" conduzirá, inevitavelmente, à impessoalidade com que a arte imanente deve ser tratada por seu autor. Curiosamente, tanto Baudelaire quanto Maupassant destacaram, além do formalismo de Flaubert, a sua impessoalidade, o que é muito compreensível, pois suas críticas dialogam com um vazio referencial da arte postulado pelo próprio romancista. Fatalmente, a impressão da pessoalidade na obra seria mais um fator metaestético a lhe justificar o significado. "Flaubert jamais escreveu a palavra eu" (1990, p. 13), eis a formulação metalinguística com que é descrita a ausência de um real biográfico, de uma homologia explícita entre a obra e a vida. Maupassant aprendeu essa lição com o próprio Flaubert, seu mestre e amigo. Para Flaubert, Baudelaire, Maupassant e a geração de escritores naturalistas, a busca da impessoalidade se realiza como um dos efeitos do real, anunciando uma possibilidade que, no século XX, será exacerbada. Lembremo-nos da ambiguidade provocadora de Marcel Proust ao nomear Marcel ao narrador de Em busca do Tempo perdido; lembremo-nos do próprio Proust, em discurso reportado no diário de André Gide, recomendando a este, ao fazer uma leitura do ensaio Corydon, que nele tudo dissesse, exceto a palavra "eu" (GIDE, 1948, p. 692) ${ }^{16}$. Enfim, Maupassant citará contraexemplos da impessoalidade: "sabe-se o que devia pensar Dickens, o que devia pensar Balzac. Eles aparecem a todo momento em seus livros [...]" (MAUPASSANT, 1990, p. 13). Podemos, então, compreender a ênfase no caráter impessoal da obra: se seu julga-

\footnotetext{
${ }_{16}$ Para um aprofundamento da admoestação de Proust, remeto ao diário de André Gide em data de 14 de maio de 1921. Ainda que 0 conselho de Proust possa ser lido como uma aversão à revelação pública de sua própria homossexualidade, ele não deixa de estabelecer profunda relação com a estética proustiana de escamoteação do eu.
} 
mento não deve vir de fora, tampouco poderia vir do autor. Dessa maneira, a impessoalidade gera o ineditismo de um leitor crítico e independente, submetido à disciplina de significar a obra por meio de sua coerência interna.

"Estudo sobre Gustave Flaubert" é um texto extenso e heterogêneo, reunindo análise, dados biográficos e da rotina de escrita do romancista na cidade de Croisset, citações de suas falas e fragmentos de cartas, a descrição do círculo de artistas recebida no apartamento parisiense, além de notas organizadas pelo autor relativas a futuras obras. Ater-me-ei às análises, sobretudo àquelas sobre o trabalho escritural e sua relação com a referencialidade externa, destacando uma em que o crítico retoma o tema da impessoalidade, apresentando uma metáfora metalinguística bastante significativa: o espelho. Ele ressalta que, para Flaubert, era inconcebível a reprodução da opinião do autor na obra, que esta "devia ser o espelho dos fatos, mas um espelho que os reproduzisse dando-lhe aquele reflexo inexprimível, aquele não sei quê de quase divino que é a arte" (MAUPASSANT, 1990, p. 29). A metáfora do espelho não era nova: Stendhal já a havia empregado como epígrafe ao capítulo XIII de O vermelho e o negro (1830), na qual se lê: "Um romance é um espelho que se carrega ao longo do caminho"17 (STENDHAL, s/d, p. 75), atribuída ao romancista e crítico Saint-Réal. Retomada por Maupassant, quando a literatura realista estava sendo largamente produzida e debatida, essa metáfora reflete, naquele momento, uma concepção moderna sobre as tensões entre a homologia com o real e a estetização do universo narrado. Ao reconhecer a existência de um "reflexo inexprimível", não estaria ele se referindo àquilo que a escrita não capta do mundo externo, mas expressa tão-somente por referências internas ao próprio espelho, isto é, à linguagem? E dirá, sobre os traços característicos das ações, que Flaubert os reunia com vistas ao "efeito que se deseja obter, e não para um ensinamento qualquer” (MAUPASSANT, 1990, p. 30). Maupassant salienta o critério da objetividade para tratamento da narração; perspectiva da qual partirá Roland Barthes, ao salientar o critério de um "verossímil estético" nas escolhas descritivas em Madame Bovary, comprometido mais com o pictórico e que "imita o que já é simulação de uma essência" (BARTHES, 1972, p. 39). O simulacro de verdade de Flaubert também é ressaltado por Maupassant, que citará as palavras do próprio romancista: "Algum dia vocês acreditaram na existência das coisas? Não será tudo uma ilusão?” (MAUPASSANT, 1990, p. 32, em itálico no original).

Por conseguinte, a paleta de cores do texto reveste o tecido descritivo e narrativo de uma existência que não remete ao enunciado: "sua frase, forçada a reproduzir coisas comuns, tem frequentemente arrebatamentos, sonoridades, tons, acima dos assuntos que ela exprime" (1990, p. 34). O enunciado (o que se relata) é superado, então, pela enunciação (como se relata): "Quando um homem, por mais bem dotado que seja, só se preocupa com a coisa relatada, quando não se dá conta de que o verdadeiro poder literário não está em um fato, mas sim na maneira de prepará-lo, de apresentá-lo e de exprimi-lo, ele não tem o sentido da arte" (1990, p. 70).

Fato é que Madame Bovary será, por seu conteúdo "licencioso", um sucesso de público entre leitores conteudistas, o que não se deve esquecer. Por outro lado, o que Maupassant prioriza em sua crítica é que obra se destina a um leitor cuja fruição estética leva à "emoção de uma beleza

\footnotetext{
17 "Un roman, c'est un miroir qu'on promène le long d'un chemin."
} 
mais elevada, mais imperceptível, mais intelectual” (1990, p. 70). Situação análoga é a do próprio Maupassant, cuja prosa refinada atingiu o pequeno burguês, o leitor comum e aquele da "fina flor cultural". Alinhou-se, assim, à arte pela arte, repudiou o utilitarismo, o gosto da multidão, o leitor conteudista, que "encontr[ou] em Musset a satisfação de todos os seus apetites poéticos um pouco vulgares" (1990, p. 70-71). Trata-se, pois, de uma linhagem de escritores, entre os quais ele enumera Baudelaire, Victor Hugo e Leconte de Lisle, "espíritos dotados desse sentido misterioso da arte, [...] como se eles se servissem de uma linguagem ignorada pelos outros" (1990, p. 71).

Pela ótica de Maupassant, o Flaubert que conhecemos anteciparia, pois, as poéticas antirreferenciais posteriores, uma vez que "batalhava desesperadamente contra a ideia e contra a palavra” (1990, p. 74-75). Curvar-se à ideia, ao conteúdo, condescender com a realidade está fora de cogitação para Flaubert; a imperfeição de uma obra não é ditada pelo referente: o defeito é do mundo, não da obra. Quanto a isso, Maupassant relata que o advertiram sobre a falta de verossimilhança da psicologia da personagem Félicité, do conto Un Cœur simple, alegando ser demasiado sutil, em comparação com a pobreza intelectual da personagem, que ela tivesse visto a imagem do Espírito Santo em um papagaio. Ele reporta-nos a reação de Flaubert: "Os senhores têm razão, [...] mas seria preciso mudar minha frase. [...] Pior para o sentido; o ritmo antes de tudo!" (1990, p. 75, itálico no original). Logo, a arte não transige com o real, é essa a lição que Flaubert deixa para a posteridade, o que Baudelaire e Maupassant trataram de enfatizar em suas críticas sobre Madame Bovary, depois de penetrarem o coração da obra e de seu criador, para quem "não há senão o estilo" (1990, p. 72).

\section{REFERÊNCIAS}

BARTHES, Roland. O Efeito de real. In: Literatura e semiologia: pesquisas semiológicas. Tradução por Célia Neves Dourado. Petrópolis: Vozes, 1972. p. 35-44.

BAUDELAIRE, Charles. Salon de 1946. In: Euvres de Baudelaire. V. VII. Paris: Gallimard, 1951. p. 61-163. (Bibliothèque de la Pléiade)

BAUDELAIRE, Charles. Les Fleurs du mal. In: Euvres complètes. V. I. Paris: Gallimard, 1983. p. 1-196. (Bibliothèque de la Pléiade)

BAUDELAIRE, Charles. Salon de 1859. In: Écrits sur l'art. Paris: Librairie Générale Française, 2010. p. $349-446$.

BAUDELAIRE, Charles. Madame Bovary por Gustave Flaubert. In: FLAUBERT, Gustave. Madame Bovary. Tradução por Mario Laranjeira. São Paulo: Companhia das Letras, 2011. p. 7-19.

CHAMPFLEURY, Jules. Do realismo: carta a Madame Sand. Tradução por Edson Rosa da Silva. ALEA. v. 16, n. 2. p. 464-473. jul-dez 2014.

COMPAGNON, Antoine. Os Cinco paradoxos da modernidade. Tradução por Cleonice P. Mourão, Consuelo F. Santiago e Eunice D. Galéry. Belo Horizonte: Editora UFMG, 1999.

CORTAZAR, Julio. A Situação do Romance. In: Valise de cronópio. 2. ed. Tradução por Davi Arrigucci Jr. e João Alexandre Barbosa. São Paulo: Perspectiva, 2006. p. 61-83. 
FLAUBERT, Gustave. Madame Bovary. Paris: Librairie Garnier Frères, 1947.

FLAUBERT, Gustave. L'Éducation sentimentale. Paris: Gallimard,1972.

FLAUBERT, Gustave. Trois contes. Paris: Gallimard, 1973.

FLAUBERT, Gustave. Correspondance. V. II. Paris: Gallimard, 1980. (Bibliothèque de la Pléiade)

GIDE, André. Journal: 1889-1939. Paris: Gallimard, 1948.

HAUSER, Arnold. História social da arte e da literatura. Tradução por Álvaro Cabral Martins Fontes. São Paulo: Martins Fontes, 1995.

HUGO, Victor. Do grotesco e do sublime. Tradução do "Prefácio de Cromwell". Tradução por Celia Berretini. São Paulo: Perspectiva, 1988.

HUGO, Victor. Hernani. Paris: Gallimard, 1995.

JAUSS, Hans Robert. Pour une esthétique de la réception. Tradução por Claude Maillard. Paris: Gallimard, 1978.

LLOSA, M. V. A Orgia Perpétua: Flaubert e Madame Bovary. Rio de Janeiro: Francisco Alves, 1979.

LUCAKS, Georg. Teoria do romance: um ensaio histórico-filosófico sobre as formas da grande épica. Tradução por José Marcos Mariani de Macedo. São Paulo: Duas Cidades; Editora 34, 2000.

MAUPASSANT, Guy de. Estudo sobre Gustave Flaubert. In: MAUPASSANT, Guy de. Gustave Flaubert. Tradução por Betty Joyce. Campinas: Pontes, 1990. p. 19-58.

MAUPASSANT, Guy de. Textes sur le roman naturaliste. Paris: Pocket, 1999.

SAINTE-BEUVE, Charles-Augustin. Madame Bovary par Gustave Flaubert. In: CÉRÉdl. Disponível em: $<$ https://flaubert.univ-rouen.fr/etudes/madame_bovary/mb_san.php>. Acesso em: 26 mar. 2021.

SAND, George, Le Réalisme. In: CÉRÉdl. Disponível em: <https://flaubert.univ-rouen.fr/etudes/madame_ bovary/mb_san.php>. Acesso em: 28 mar. 2021.

STENDHAL. Le Rouge et le Noir. Paris: Librairie Garnier Frères. s/d.

WILLIAMS, Raymond L. A ficção de Milton Hatoum e a nova narrativa das minorias na América Latina. In: CRISTO, Maria da Luz Pinheiro de (Org). Arquitetura da memória. Manaus: Editora da Universidade Federal Amazonas/UNINORTE, 2007.p. 162-170.

YOSHIO, Abe. Baudelaire et la peinture réaliste. Cahiers de l'Association internationale des études françaises, n. 18, p. 205-214, 1966. 